\title{
Epigenetics AND Politics IN THE Colonial Present ${ }^{1}$
}

\author{
Karen Bridget Murray
}

Abstract. This article draws attention to the importance of including the colonial present in critical inquiries into the relationship between epigenetics and politics. Focusing on British Columbia (Canada) at the dawn of the twenty-first century, the assessment illustrates how an epigenetic style of thought rendered tangible the "vulnerable Aboriginal child" as a category amenable to settler-colonial governmental interventions. More specifically, the article demonstrates how prominent elements of this classification interconnected with a mediating device undergirded by epigenetic reason, the Early Development Instrument. Eugenic sensibilities produced through epigenetic logics wove through this relationship. In turn, linkages between the EDI and the classification of the at-risk Aboriginal child comprised a terrain that shaped settler-colonial power and privilege through mechanisms of population management and related implications for territorial control. The article evaluates what these findings suggest for extending debates about the political elements of epigenetic reason.

Keywords: Epigenetics; mediating device; Early Development Instrument; settler-colonialism; vulnerable populations.

Résumé. Cet article attire l'attention sur l'importance d'inclure le présent colonial dans les examens critiques de la relation entre l'épigénétique et la politique. En se concentrant sur la Colombie-Britannique (Canada) au début du XXIe siècle, l'évaluation montre comment un style de pensée épigénétique a rendu tangible $1^{\text {' } ~ " ~ e n f a n t ~ a u t o c h t o n e ~ v u l n e ́ r a b l e ~ » ~ e n ~ t a n t ~ q u e ~ c a t e ́ g o r i e ~ s o u m i s e ~}$ aux interventions des gouvernements coloniaux et coloniaux. Plus précisément, l'article montre comment des éléments importants de cette classification sont interconnectés avec un dispositif de régulation, soutenu par le raisonnement épigénétique, l'Instrument de mesure du développement de la petite enfance

1. I extend my gratitude to the four anonymous reviewers who gave so generously of their time to comment on ideas developed herein, as well as to editor Kevin Haggerty for patiently and thoughtfully ushering the article through to completion. Very special thanks to Peggy (Margaret) Chiappetta for reading the penultimate draft and for offering such thoughtful feedback, and to Lina Nasr El Hag Ali for exemplary translation services. All errors are, of course, my own. 
(IMPDE). La sensibilité eugénique, construites par des logiques épigénétiques, sont tissés tout au long de cette relation. Ensuite, les liens entre l'IMPDE et la classification de l'enfant autochtone à risque, comprenait un terrain qui façonnait le pouvoir et les privilèges coloniaux par le biais de mécanismes de gestion de la population et leurs implications pour le contrôle territorial. Cet article évalue ce que ces résultats suggèrent pour augmenter les débats sur les éléments politiques de la raison épigénétique.

Mots-Clés: épigénétique ; dispositif de régulation ; Instrument de mesure du développement de la petite enfance ; colonialisme ; populations vulnérables ;

\section{INTRODUCTION}

am the daughter of an Irish settler-immigrant and the granddaughter of Volga German settler-immigrants. I was born in the place that many, but not all, refer to as Victoria, British Columbia.

For most of my life I was unaware that my early years were spent as a visitor on the respective traditional territories of the Lkwungen, WSÁNEĆ, and Wyomilth Peoples. ${ }^{2}$ Later, I lived on the traditional and unceded territories of the Coast Salish Peoples, namely the shared traditional territories of the Skwxwú7mesh Úxwumixw (Squamish), Tsleil-Waututh, and $\mathrm{x}^{\mathrm{w}} \mathrm{m} ə \theta \mathrm{k}^{\mathrm{w}}$ əy่วm (Musqueam) and Kwikwetlem First Nations; and then on the traditional unceded territories of the Mi'kmaq and Wolastoqiyik Peoples covered by Treaties of Peace and Friendship. Today, I live and work on the territories of many Indigenous Nations at Tkaronto: the Wendat, the Anishinabek Nation, the Haudenosaunee Confederacy, the Mississauga of the New Credit First Nation, and the Métis (Canadian Association of University Teachers 2018).

I make these land acknowledgements knowing that they are empty and self-congratulatory gestures unless I am also writing to support treaties, Indigenous Peoples' self-rule, restitution, and the returning to Indigenous Peoples their lands and their children. While my research has long focused on trying to make visible and subvert power relations that sustain inequalities and injustices, I have come to understand that

2. I use the term "Aboriginal" when referring to policies and practices that employ this terminology. Otherwise, I use the term "Indigenous Peoples" to denote "an identity constructed, shaped, and lived in the politicized context of contemporary colonialism" (Alfred and Corntassel 2005). Where possible, I use the names of specific First Nations communities, which are legally defined self-governing territories and communities. I continue to learn about how to properly acknowledge land. The acknowledgements herein are based on the language suggested by the Canadian Association of University Teachers (2018). 
ignoring the colonial present (as I have done) is part of the problem. Silence has effects. By placing myself in this way, I am following Sarah de Leeuw and Sarah Hunt (2018) who argue that situating oneself within the "authorial position" is an "important step in writing about and envisioning practices of decolonization" (3).

I begin with an observation. Amidst the explosion of scholarly interest in the relationship between epigenetics and politics is a ringing silence created by the almost complete lack of attention to the colonial present (Coulthard 2015). This article aims to illustrate how centering the colonial present not only extends the empirical and theoretical reach of inquiries into politics and epigenetics, but also how inaudibility on such matters is part of the perpetuation of colonial harms.

Focusing on Canada from the early 1990s into the first decade of the new millennium, my goal is to show how a mediating device grounded in epigenetic reason, the Early Development Instrument (EDI) (McMaster University 2000 [2017/2018]; Offord Centre for Child Studies 2016a and 2016b), operated as a tool of settler-colonial power in relation to the classification of the "vulnerable Aboriginal child."

Following Margaret Chiappetta and Kean Birch (2018), I define a mediating device as a technological instrument based on "intangible assets" such as data and information that shape power relations via knowledge production, collaboration, and circulation (65-66), which in the case of the EDI have traversed colonialist, capitalist, and eugenic mentalities and practices. As I will explain, the EDI's value generating properties were fashioned through the production of statistically defined "vulnerability rates" contrived from data extracted from assessments of children's minds (cognitive and language skills), bodies (physical health), and souls (social and emotional expression). In significant ways, these processes were shaped by and also shaped the category of the atrisk Aboriginal child. The article dives deeper into these matters by assessing aspects of the EDI project in British Columbia ("BC EDI project"), which hinged on a partnership between the Province of British Columbia and the University of British Columbia (UBC). Among other things, the BC EDI project supported pan-provincial EDI surveying, evaluations and policy research through UBC's Human Early Learning Partnership ("the HELP") (Agreement 2002: 3, 9, 10). It did so in ways that further augmented the legibility of images of the vulnerable Aboriginal child, including through connections to a program known as StrongStart BC ("StrongStart"). Through this street-level program, we see how this population-level category intersected with individualized interventions, including ones that raise troubling questions about connections to 
the legal basis for forcible child relinquishment, and by extension matters relating to Indigenous jurisdiction over their territories and children.

After a discussion of analytical framing and research steps, the article's central arguments are developed in three analytical vignettes. The first vignette traces out a genealogy of the birth of the EDI. The second vignette is a genealogy of the category of the at-risk Aboriginal child in relation to EDI mediations, with particular attention to the launch of the BC EDI project. The third vignette undertakes an archeological inquiry into the administrative-legal character of StrongStart, paying specific regard to how the program raises questions about processes relating to involuntary child relinquishment. The conclusion reflects upon how these vignettes underscore some of the flaws but also implications of ignoring the colonial present in critical approaches to the study of the relationship between politics and epigenetics.

\section{Analytical Frame and Research Steps}

Some scholars treat epigenetics as settled science that has political ramifications (e.g., Hedlund 2012; Robison 2017; Rothstein et al 2009; Rothstein et al 2017). Within this orientation, as Maurizio Meloni (2017: $15)$ points out, some see epigenetics as a basis for demanding reparations for epigenetic harms, including those stemming from colonialism. This article follows those who have said that more caution needs to be exercised in such assessments because epigenetics is not a settled science (Keller 2014). Discredited in many circles (Gillies et al 2017: 1200; Meloni 2016: 138; Meloni and Testa 2014; Petersen 2016; Pickersgill 2016; Wastell and White 2017), epigenetics is said to have been "served before its time" (Juengst et al 2014; see also Waggoner and Uller 2015).

This article follows those who focus on epigenetics as a style of thought, as "a particular way of thinking, seeing, and practicing" (Rose 2007), a terrain of "political biology," an "ambiguous and contingent space where science is mobilized on behalf of politics" (Meloni 2016: 16).

As a style of thinking, epigenetics derives from an assemblage of knowledge claims (Wastell and White 2015: Chapter 2) that challenge the once accepted wisdom that genes exclusively determine biological development. Broadly understood, epigenetic reason emphasizes how gene-environmental interactions shape genetic expression, even while genes do not change. Faulty gene-environment interactions have been pointed to as producing a range of risks and outcomes relating to diseases and behavioural problems, including "anti-social" conduct (Gillies 
et al 2017: 1172; Hertzman 1999: 87; Hertzman 2011a and 2011b). A controversial assertation is that genetic expressions can be transmitted "not only over someone's lifetime via cellular reproduction, but also from one generation to another, even when the environmental signal has been switched off' (Meloni 2016: 4112).

Behavioural epigenetics is particularly contentious. Within this subfield, the ostensible failings of pregnant or pre-pregnant women (Kenney and Müller 2017; Mansfield 2012: 355) and shortcomings in parental conduct have been a major focus of concern, especially when seen as geographically clustered. This emphasis on bio-social reproduction stems from the view that in utero environments and the character of parent-child relationships, usually that between mothers and their children, are crucial factors shaping an offspring's genetic expression, which some see as having potential life-long and deleterious effects (HELP nda; Hertzman 1999). Such concerns have been the basis for place-sensitive interventions to create optimal epigenetic environments (Gillies et al 2017; Murray 2015: 284). Sometimes such logics have depicted those deemed to be epigenetically-compromised as a hindrance, even a threat, to the optimal development of others, that is as elements of a supposed epigenetically deficient environment (Hertzman 2011b; Murray 2015).

There is insightful critical work among scholars who have variously argued how epigenetic reason shapes and is shaped by divisions along gender, race (Kenney and Müller 2017; Mansfield 2012; Meloni 2017; Richardson 2017; Saldaña-Tejeda 2018; Saldaña-Tejeda and Wade 2018; Saulnier and Dupras 2017), and class lines (Meloni 2016: 218), as well as by eugenic mentalities and practices (Mansfield and Guthman 2015: 14, 16). Research has also highlighted how epigenetics' geo-spatial premises challenge conventional political epistemologies (Pentecost and Cousins 2017; Stallins et al 2018), raising the matter of what geographer J. Anthony Stallins et al (2018) call "cartographic translations" (162) that bring certain bodies and places into visibility as a "new DNA" (154).

This article speaks to a void in these critical investigations, namely the almost complete absence of attention on the colonial present. With important exceptions (Saldaña-Tejeda 2018; Saldaña-Tejeda and Wade 2018), the colonial present is typically ignored or treated as a past "phase" (Meloni 2016: 136), rather than as a set of enduring relations.

To address this silence, I follow Patrick Wolfe's (2008) definition of settler-colonialism as an ongoing structure that is "first and foremost a territorial project, whose priority is replacing natives on their land" through "elimination as an organizing principle" (2740-2763). Among other things, this definition draws attention to two interlocking dynamics of power, population management and territorial control, each made 
visible through various forms of calculation and measurement (Elden 2013a: 35; Elden 2013b: 17) tied to political styles of thought.

The EDI, as a mediating device for the epigenetic style of thought, relates to the intertwined dynamics of population management and territorial control in specific ways in the settler-colonial context of Canada, which has long and well-documented record of forcibly removing Indigenous children from their communities, at times with fatal consequences (Murray 2017; Truth and Reconciliation Commission 2015).

Many scholars and children's rights advocates have highlighted the disproportionate number of Indigenous children in the hands of settlercolonial child welfare systems across Canada (Blackstock 2003: 331; Blackstock 2015; De Leeuw 2014; Jacobs 1992; Kline 1992 and 1994; Monture 1989; Ontario Human Rights Commission 2018; Representative for Children and Youth in British Columbia 2013; Salmon 2004; A. Simpson, 2014; Turpel 2011). For example, in 1997, while Census-defined Indigenous populations accounted for 7 percent of British Columbia's population, 31 percent of children under the direct jurisdiction of the Province of British Columbia were Indigenous. In 2005, the percentage rose to 49 percent (British Columbia and Child and Youth Officer for British Columbia 2006: 10). In 2018, in the Province of Manitoba, 90 percent of the 11,300 children in government care were Indigenous (Geary 2018). In 2013, children living on reserves ${ }^{3}$ in Canada collectively spent roughly 300,000 days in "funded days of care" (Sinha et al 2018: 17).

Indigenous children in contact with provincial child protection systems have higher fatality rates than non-Indigenous children. In the Province of Alberta, the Office of the Child and Youth Advocate found that among the 252 reported youth suicides between April 1, 2012 and March 31, 2017, over 70 percent involved Indigenous children. All of these children were either under the province's control or had some involvement with its child intervention system (Office of the Child and Youth Advocate Alberta 2018: 5, 27). In British Columbia, the Representative for Children and Youth examined the circumstances surrounding deaths of 21 infants under the age of two over a roughly two-year period from 2007 to 2009. All of the children had some contact with the province's child protection services. Fifteen of these infants were Indigenous. Province wide in British Columbia, in 2011, the "mortality

3. "Reserves" are legally-defined "tracts of land set apart by treaty or otherwise for the use or benefit of or granted to a particular band of Indians, of which legal title is held in the Crown, but which is unsurrendered," as per An Act to Amend and Consolidate the Laws Respecting Indians, Statutes of Canada 1876, Chapter 18 (the "Indian Act"). 
rate for Status Indian infants" was "twice that of non-Aboriginal infants" (Turpel 2011: 3-5).

Indigenous Peoples have unceasingly refused settler-colonial dispossessions, including by demanding full control over their children as part of reclaiming lands and pushing back against territorial encroachments (Hunter, 2018; Jacobs 1992; A. Simpson 2014; L. Simpson 2014; Simpson 2016; Union of BC Indian Chiefs 2002: 6). In British Columbia at the dawn of the new millennium, such refusals played out in a setting where two-thirds of Census-defined Aboriginal peoples - including 203 First Nations speaking 20 distinct languages - held non-ceded territory covering most of the province (BC Assembly of First Nations 2018; Justice Education Society and Centre for Education, Law and Society 2017).

It is in this settler-colonial milieu that we find, beginning in the early 1990s, the epigenetic style of thought coming to touch an expanse of policies and programs under the rubric of early childhood development, including by the new millennium through EDI mediations. And yet, very few critical studies have recognized the centrality of the epigenetic style of thought or considered the EDI's political and governmental import (Einboden et al 2013; Peers 2011). Apparently, with one exception (Murray 2015), almost nothing has been said about the EDI as it relates to the colonial present.

In the analysis to follow, I evaluate the political dimensions of epigenetics running through EDI mediations by drawing upon two related neo-Foucaultian methods: genealogy and archeology. The first two vignettes are genealogical. Genealogy is a historical lens, but not of the conventional kind. It does not seek to identify causes and effects, to find an inherent truth about the past, or to expose ideas as smokescreens for what is really happening. The aim is to trace out lineages of knowledge claims, comprised of both language and practices, silences and audibility, and to ascertain the forms of power they produce, such as political subjectivities (Murray 2007: 162-165) and territorial boundaries naturalized through them. From these angles, we see how, to use Michel Foucault's (1979) words, "power and knowledge directly imply one another" (27). Seeing power in this light shows that the framing of child development as an epigenetic problem limits the horizon of possibilities of thought and action. These assumptions, widely (but not totally) accepted and derived from language and technique, are what Foucault referred to as unitary discursive practices, otherwise known as discourse (Rose 1996a: 128-31; Rose 1996b: 105). The third vignette, which focuses on the StrongStart program, is archeological in its orientation. Archeology (Foucault 1972) shares genealogy's understanding of power, but instead of focusing on "historical processes" it cuts a "historical slice" through 
a set of discursive practices (Kendall and Wickham 2003: 31). Slicing through StrongStart's administrative-legal linkages to the EDI illustrates how population classifications were connected to individualized mechanisms of power that further reinforced problematic images of the at-risk Aboriginal child and their related implications.

These methods are brought to bear through a reading of an eclectic set of documents. In addition to publications and reports produced by the EDI's would-be designers and proponents, I examine an array of promotional materials, policy documents, government statements, regulations, guidelines, and laws, as well as selected survey instruments, including the EDI. Some materials were gathered under the Access to Information Act [R.S.C. 1985 c. A-1) of the Government of Canada, as well as the Freedom of Information and Protection of Privacy Act [RSBC 1996; Chapter 65] (FOIPPA) of the Province of British Columbia, the latter yielding hitherto unreleased contracts between the government and UBC that established the BC EDI project. The complement of these (usually) triennial agreements included expectations and rights of the parties, but also detailed research plans. I have chosen to focus primarily on the 2011 agreement (Agreement between Her Majesty the Queen in Right of the Province of British Columbia, represented by the Minister of Children and Family Development and the University of British Columbia; after this, each agreement will be referred to as "Agreement" with its corresponding date). By then, EDI mediations had a certain durability. The $\mathrm{BC}$ EDI project's style of thinking and practices were ten years on and StrongStart had been operating for approximately five years.

One cannot assume, of course, that the governmental character of the relationship between the EDI and the classification of the at-risk Aboriginal child interpreted through these texts was always or necessarily reflected in concrete implementations. The article has other limitations. It does not address conflicting mentalities, and it only minimally speaks to resistance to the logics identified. While deeply critical of the programmatic translation of epigenetic reason, I do not discount the potential that some people might have benefitted from them in some way. Concerns with justice and equality no doubt animated the ambitions of many people involved in shaping the EDI and its circulations. To be clear, my concern is not with intent. The article is focused on express statements and their effects, such as in terms of what is construed as normal and abnormal, ideal and deviant, optimal and suboptimal and so on, and their related ramifications for the colonial present. Much more needs to be known about the EDI and its mediations in relation to the vulnerable Aboriginal child category. This article, as a contour sketch, is a beginning, not an end. 


\section{The Birth of the Early Development Instrument}

As I have discussed elsewhere (Murray 2015), the EDI traces back to the work of the Canadian Institutes for Advanced Research (CIFAR), established in 1982 under its influential founding president, J. Fraser Mustard, who spearheaded Canada's population health agenda. A medical doctor, health researcher, academic and university administrator with close ties to corporate Canada and political officials across the ideological spectrum (Hayes and Dunn 1998; McMaster University 2009; White 2017: 140, 209-210), Mustard was well-placed to build the network of likeminded researchers who would champion new ways of thinking about child development, of which the EDI would be a crucial part (Mustard 2009: 644; Mustard 2010). While Mustard's close associates Dan Offord and Magdalena Janus would be the named crafters of the EDI, many people played a role in its making, including Mustard who came up with the idea, encouraged its development, and later would become one of the EDI's leading advocates (Santos et al 2012: iii)

The EDI surfaced within a set of colonialist sensibilities, the inklings of which were evident in a 1988 article that Mustard co-wrote with Geraldine Kenney-Wallace, the then newly-appointed chair of the Science Council of Canada. The article's main argument was that universities and industry needed to align in a renewed nationalist project. Overtly mentioning colonialism as part of Canada's Commonwealth relationships, Kenney-Wallace and Mustard claimed that "natural resources [were] no longer the most valuable currency." Canada, they said, would need to "shift its attention to developing its human resources." The article ignored Indigenous Peoples' territories and rights, including those entrenched in the Constitution Act (1982). What for Indigenous Peoples are their territorial jurisdictions were, for Kenney-Wallace and Mustard, Canada's historical "resource riches" (Kenney-Wallace and Mustard 1988:191-93).

Along with other associates at CIFAR, Mustard attached such concerns to an epigenetic-based problematization of child development, as was apparent in The Learning Society (1992), the founding statement of CIFAR's Human Development Program that would be set up in 1993 (44). The report brought into visibility an evolutionary biological way of seeing child development trained on what was, in effect, a eugenic division between optimization and sub-optimization. The optimally developed human was overtly defined as "informed" and "lively," with an "engaged mind," a "rational" person, one who was skillfully intuitive, civil and imbued with "values." This idealization brought its opposite into visibility: the uninformed, docile, disengaged, irrational, unintui- 
tive, uncivil, valueless, sub-optimal human. The optimal would be the bedrock of wealth, stability and order in a technologically driven world. The latter, a danger to the same. The goal of monitoring this supposed threat and acting upon it from the time of conception to the early years of life, when the conditions for optimization were said to be most pronounced, set the stage for the creation of the EDI (CIFAR 1992: 8-9, 22, 52).

Against this backdrop, Indigenous Peoples were discussed in relation to a problematization of "exclusion," which The Learning Society saw as especially apparent in large urban areas, the same places that Mustard and his associates understood as the linchpins for building Canada's competitiveness in new knowledge markets. Cities were described as the historical locus of "civilization," but also under threat by, among other things, "congestion, crime, and violence" (CIFAR 1992: 2, 22). The Learning Society sought to address what it saw as a fundamental paradox: "dependence on information and knowledge for the production of value" were the bedrock of emerging new markets, but these same processes were "weaken[ing] ... the very institutions that [had] traditionally been most central to the development of ... human resources: namely, the family, the school, and the community" (CIFAR 1992: 11, 22). Such mentalities tacitly hinged on a way of seeing cities as, to use the words of Yellowknives Dene First Nation scholar Glen Coulthard (2014: 3700), "void of Indigenous sovereign presence," that is urbs nullius. They also had a family resemblance to historical discourses that had defined Indigenous Peoples as pre-modern and uncivilized, which of course, in some sense, mirrored the division CIFAR articulated between optimal and sub-optimal humans.

The Learning Society argued that by "includ[ing] previously excluded groups on an equitable basis, particularly [I]ndigenous [P]eoples and those from minority cultures" (CIFAR 1992: 2, 31), Canada could fortify its global competitiveness by embracing its socio-demographic diversity as a strength $(35,57)$. Wedded to this goal was an emphasis on creating "developmentally and culturally appropriate learning experiences" (9), specifically at the time of transition to school entry, namely during kindergarten and pre-kindergarten. Particular focus would be placed on "children from outside the mainstream," which was described as "white and middle class" $(5,22,31)$.

That an epigenetic rationale was central to how The Learning Society envisioned "inclusion" was clear in that the plans proposed to promote optimal development hinged upon a seamless application to the human world of findings from behavioural studies of the rhesus macaques (CIFAR 1992: 2, 6, 22-28). "[P] articularly informative models [could] be 
derived," it was said, "from Old World monkeys (such as the rhesus), among who the degree of genetic overlap with humans ranges from $90 \%$ to $98+\%$..." (33). The report highlighted that some monkeys genetically vulnerable end[ed] up at the bottom of the social hierarchy in adulthood" (27). It also noted that problematic effects of genetic tendencies could be staved off by intervening in vulnerable monkeys' early years, specifically by placing them in the care of "high status" and "highly nurturant" surrogate mothers. For CIFAR's Human Development Program, this meant that genes were not determinative. Environmental conditions could be manufactured to reduce genetic limitations (CIFAR 1992: 4, 49). And, within these mentalities, forced adoption was understood to be a technique for optimizing child development. This would require, of course, observing and classifying mothers according to the presumed risks they posed to their kin.

Building a programmatic line of action according to such logics, and pointing to a research demonstration project in Winnipeg as a model, Mustard and CIFAR affiliate Daniel Keating argued (1993) that developmental "disabilities [set] early life" could be overcome by "structur[ing] both physical and social environments [to] provide supportive interaction," including through "non-biological parenting" of children in "high risk-environment[s]" (98).

The brainchild of Don Lugtig and Don Fuchs (1992) of the Faculty of Social Work at the University of Manitoba, the Winnipeg project aimed to develop neighbourhood-based interventions to prevent child maltreatment through "support for parenting," which included "a vulnerability to child maltreatment risk scale" (3). The initiative was in the inner-city, in an area with higher-than-average numbers of single mothers, people with low incomes, new immigrants and Indigenous Peoples (Lugtig and Fuchs 1992: 4, 16-19; 23; 35). The rationale for the undertaking derived from the work of James Garbarino, professor of psychology at Loyola University, who coined the term "socially toxic environments" (1995: 24). Garbarino was also influenced by studies of the non-human animal world, specifically gorilla behaviour, which suggested peer-to-peer interactions ameliorated problematic gorilla mother conduct toward their kin. Based on such thinking, Garbarino argued one-on-one interventions should be less of a focus of government policy, and that environmental interventions in "high[-] risk neighbourhoods" should be more of a focus (Garbarino 1980; Garbarino and Kostelny 1994; Garbarino and Sherman 1980). In a summary of a presentation given by Fuchs, and with echoes of the premises derived from the rhesus macaques research CIFAR drew upon, the Winnipeg project was described as including efforts to diversify participants' experiences by placing parents with people outside of 
their ordinary group (Fuchs 1994: 45-46). In effect, this model treated risks to children as individualized, localized and disconnected from wider structures of oppression, including colonial variants, which might have otherwise been a basis for solidarity building. It did so, moreover, according to expert norms that problematically labelled certain parents as potential threats, while also providing a means to bring such parents into professional visibility for additional assessment and judgment.

It was against this backdrop that Reversing the Real Brain Drain: Early Years Study - Final Report ("The Real Brain Drain") was released in 1999. Commissioned by the Province of Ontario and prepared with contributions from various CIFAR affiliates (Appendix 1), the report was co-authored by Mustard and Margaret McCain, member of the McCain foods empire. This report declared: "the time is now for a major effort by all parts of society to improve the opportunities for optimal early child development and parenting for all families ..." (3). Specific attention was paid to the need for "early childhood development and parenting program $[\mathrm{s}]$ " from "conception to entry into grade one." While many saw this proposal as an argument for universal day care to support working parents, the report stated otherwise, making clear that parents could "choose to bring their children or not" (17), with daycares being one potential location for parenting centres. The point was to "focus on parent interaction with their children and play-based problem solving with other children." This, it was said, would "stimulate early brain development through the sensing pathways" (37). The report called for a broad-based application of such parent training and observation programs, stressing the need to take "into account cultural, linguistic, religious and other characteristics ... important for families in the early period of child development" (McCain and Mustard 1999: 10), including by being "sensitive ... to Aboriginal communities ... [,] which needed to be assured that their young children [were] nurtured in the values and languages of the First Nations" (123). That these centres in some measure assumed the existence of parental threats to children was clear in that police services (122) were understood as being a crucial element of the undertaking. Community police officers, it was said, might even "provide volunteer assistance" (143).

Tacitly promoting the EDI, which had already been finalized, The Real Brain Drain maintained that an important piece of implementing early childhood development and parenting centres would be developing a "readiness-to-learn measure" to be applied prior to school entry (19).

The formulation and promotion of the parent-training centre idea had, in fact, gone hand-in-hand with the creation of the EDI, which emerged from Mustard's and other CIFAR associates' efforts to find ways of "col- 
lecting and organizing existing data on suboptimal development, and the barriers or blocks that operate in such circumstances" (CIFAR 1992: 44), with the National Longitudinal Survey on Children and Youth ("NLSCY") being the flagship enterprise. Established in collaboration with Statistics Canada, the NLSCY would run every other year between 1994 to 2009 with the objective of following a sample birth cohort through to early adulthood for the purposes of determining "factors influencing a child's social, emotional and behavioural development and to monitor the impact of these factors over time" (NLSCY 2011).

Soon after the NLSCY's launch, CIFAR began, in 1997, working with the Government of Canada (Human Resources Development Canada) on what would become the EDI (Mustard 2000: 14). The EDI would incorporate sixty percent of the NLSCY's questions into its roughly 100 items. It would be officially characterized as a mechanism for collecting information on children's "readiness for school" as "a proxy" for vulnerability (Janus 2006a: 1). The designers of the EDI aimed to make it a cost and time feasible "[i]nstrument to measure the outcomes of the early years," to "[c]over all relevant developmental properties - reflective of brain development," to make results "psychometrically reliable at the individual level," and to construe a tool that would be "[a]dequate to monitor and report on populations of children" (Janus 2006b).

The EDI's questions were divided into five "scales" that mirrored the NLSCY's factors of measurement: "physical health and well-being; social competence; emotional maturity; language and cognitive development; and communication skills and general knowledge" (Janus and Offord 2007). Kindergarten teachers were to take 10-15 minutes to fill out the EDI checklist on children with whom they had approximately six months' contact (Janus 2006a; McMaster University 2000 [2017/2018]). In this way, epigenetically-oriented norms were fashioned as objective and discernible by people who had only limited interaction with any given child. Among other things, the collected data would then be used to construct a population-level statistical "vulnerability rate" derived from a "normative sample" of 116,860 children (Janus 2006b). The designation "vulnerable" would apply "to children who score[d] in the lowest 10th percentile on one more [of the EDI's] scales" (Offord Centre for Child Studies 2016c; see also Janus 2006b; Janus et al 2007: 2, 10; Mustard 2009: 653)

The presumed veracity of vulnerability variations, made tangible through tables and maps, hinged on securing high EDI participation rates, which, in British Columbia, would sometimes push towards 100 percent. Two interconnected features of the survey process supported these high rates. First, provincial government classrooms were the pri- 
mary data collection sites, where kindergarten children were readily available as data sources. Second, the research used the lowest bar of parental consent - passive consent (HELP 2018; Janus et al 2007: 13-14; Schonert-Reichl 2017).

As a mapping tool, the EDI aligned with the epigenetic premise that families and the neighbourhoods in which they lived made children "school ready" or not, vulnerable or not (Offord Centre for Child Studies 2016c), with the latter pointing towards the need for geographically nuanced interventions to optimize development along epigenetic lines (Agreement 2002: 2; Janus et al 2007: 2, 10), such as the parent-training and observation institution envisioned by Mustard and his colleagues.

One way that the EDI operated as a mediating device was in relation to the value it generated, which aligned with neoliberal forms of governing, by which I mean a spatially and temporally diverse orientation that marketizes life itself, with the expectation that people will "comport themselves in ways that maximize their capital value in the present and enhance their future value" (Brown 2015: 190). The EDI's framers celebrated its use value, specifically its cost-saving potential. The Offord Centre for Child Studies at McMaster University (initially called the Canadian Centre for Studies of Children at Risk), the EDI's official birthplace stated: "Reporting on [vulnerable] children reflects the fundamental premise on which the EDI's concept has been built. It reflects the population that we are most likely to shift without costly and intensive interventions" (Offord Centre for Child Studies 2016d and 2018). The EDI also had exchange value. It produced a vulnerability knowledge market, generated through labour, and grounded in assessments of data scraped from the minds, bodies and souls of children. The EDI was a product, its usage sellable according to strict terms dictated by Offord Centre for Child Studies (Janus et al 2007; Offord Centre for Child Studies 2016c). Consultants could promote its ideological premises and supposed scientific truthfulness (Mustard 2009: 657). This exchange value aligned with CIFAR's dream to position Canada as a leader in global information-based markets, especially the highly coveted urban markets where most research would occur.

At the centre of the EDI's value-generating dynamics was a new way of thinking about children and mothers, a new terrain of normative subjectivity, according to eugenic sensibilities deriving from an epigenetic style of thought. A key premise woven into EDI mentalities was that it would not be enough for mothers to be employed or self-sufficient, not enough to be fully marketized. Mothers would also have to be "good." And good mothering would be decipherable through epigenetic reason. While in some respects, these discourses construed all mothers as pot- 
entially dubious (CIFAR 1992: 11), rhesus macaques research supposedly proved that high status and high achievers were coterminous with goodness in mothering or would-be mothering (see also CIFAR 1992: 54). Similarly, CIFAR's development agenda centrally focused on the supposed suboptimal mother, as prominently the low-status mother, the low-income mother, the unemployed mother, and particularly the mother on income supports, even more so when linked to "high risk multi-ethnic and multicultural neighbourhoods" (Fuchs and Lugtig 1989). And among the many classificatory schemes in which these elements would be made legible, none would be as paramount as one: the vulnerable Aboriginal child.

\section{The Discovery of the Vulnerable Aboriginal Child}

The category of the vulnerable Aboriginal child traces back to the early 1990s, which was marked by shifts in child welfare as a concept and set of practices, all of which played out sharply in British Columbia. First, there was a mutation from a "preserve families" model of child protection towards a risk assessment approach. Whereas forced removal of children had previously taken place when actual harms occurred, a new orientation emerged where the possibility of involuntary child relinquishment was triggered where there were suspicions of potential harm (Anglin 2002: 244; Grant et al 2017: 443). This change went hand-inhand with a new definition of child maltreatment. Previously, experts had defined maltreatment as battery and sexual abuse, but a wider perspective surfaced focused on "emotional, social, and cognitive effects of a range of forms of maltreatment, including neglect, emotional maltreatment, and exposure to intimate partner violence" (Mathews and Kenny 2008: 51; Trocmé et al 2011: 23). These factors would be, as we have seen, mirrored in the EDI's five domains of vulnerability assessment, which I describe as evaluations of children's minds, bodies, and souls. Concerns also arose over physician underreporting of abuse (Kempe et al 1962), and this set the stage for the expansion of the legal duty to report suspicions of maltreatment. The Province of British Columbia's Child, Family and Community Service Act, passed in 1996, incorporated these new sensibilities, including the broader expectations for mandated reporting, which became legally applicable to any person with "reason to believe" a child needed protection (14.1).

These changes emerged in tandem with growing attention on Indigenous children following the 1992 death of 6-year old Matthew Vaudreuil, who was murdered by his mother, Verna Vaudreuil. Justice Thom- 
as Gove's report (1995) into the child's death raised a concern about a lack of "certainty about aboriginal ancestry" (vol. 2, s. 77. and 78), even though Vaudreuil, an impoverished woman who faced extreme disadvantages, was not reported to be an Indigenous person. Rejecting the provincial government's "strength" model of children's service delivery, which placed faith in parents' "innate nurturing capacities," Gove called for a new method geared towards identifying at-risk groups, including through assessments "weighing factors [concerning] family history" (Gove 1995: vol. 2). Written submissions from a variety of groups were accepted by the inquiry, including from Indigenous Peoples' communities, who expressed "deep distrust" of government workers, concern with a lack of funding for child welfare services for Indigenous children, and the importance of "providing their own child protection services [as] part of their inherent right to self-government" (Gove 1995: vol. 1). The provincial government pursued a different approach, launching its firstever standardized child protection risk measurement (Greaves et al 2002: 40).

Meanwhile, Indigenous pregnant women were being singled out in a "moral panic" (Armstrong 2003; Salmon 2004) over "fetal alcohol disorder" ("FAD"). A deeply problematic diagnosis that trained attention on pregnant bodies, FAD was widely believed to lead to a host of pathologies (Boyd 1999: 101), including criminal conduct. The term FAD derived from an article published in 1973 in the Lancet. The article included three case reports involving "American Indians" (Armstrong 2003: Chapter 3). Subsequent discussions often ignored the known implications of poverty suggested in these reports. Along the way, FAD and its variants (e.g., fetal alcohol syndrome, fetal alcohol effects) came to be often loosely diagnosed, even by people without any medical training (Boyd 1999: 100-101). Indigenous Peoples were by far the most likely group to be "diagnosed" as having FAD (Salmon 2004). Thus, when, in the early 1990s, some provincial governments in Canada sought legal authority to push pregnant women into alcohol addiction treatment, they were, in effect if not by design, focusing heavily on the Indigenous pregnant body. After the courts refused to extend this legal authority, governments doubled down on prevention measures for at-risk groups (Weir 2006: 147).

The Canadian Incidence Study of Reported Child Abuse and Neglect (CIS), which ran in three cycles from 1998 to 2008 (CIS 2008; Trocmé et al 2001: ix), included elements that reflected these sorts of concerns. The CIS built upon the Ontario Incidence Study of 1993 (Canadian Child Welfare Research Portal 2011a), designed under the guidance of Dan Offord (Trocmé 1994), as mentioned, one of the official co-creators of the 
EDI. With core funding from the Government of Canada (Public Health Agency of Canada), the CIS was devised to be a "foundation for a national surveillance system on child maltreatment" for the purposes of "strengthen[ing] the national knowledge base on the incidence and characteristics of child abuse and neglect" (Trocmé et al 2001: xi). The first CIS population samples included "three aboriginal sites" and "native child welfare" was mentioned as a particular point of interest (Trocmé and Wolfe 2001: 3, 7, 25). In 2008, a "First Nations component" was included (Canadian Child Welfare Portal 2011b).

The 2008 version of the CIS included a query about a caregiver's history in foster care or group homes. This question would have had magnified salience for calculations relating to Indigenous Peoples for reasons already discussed, namely the long history of disproportionate numbers of Indigenous children placed in the fostering system, often as a result of forced relinquishments (Blackstock 2003). The CIS also included a question about the caregiver or the caregiver's parent's attendance at residential schools (CIS-2008). Between 1876 and 1996, one hundred and fifty thousand Indigenous Peoples were sent to residential schools, which were rife with neglect and abject violence resulting in thousands of deaths, often expressly recognized by the Government of Canada (Murray 2017; Truth and Reconciliation Commission of Canada 2015). As Sindha et al (2018) point out, "the choice to focus research on the overrepresentation of any group indicates an implicit concern that child welfare engagement may be harmful, inappropriate, or not meeting the needs of members of the overrepresented group" (19). Questions need to be raised, therefore, about how the CIS shaped problematic images relating to Indigenous Peoples.

Over a related plane of knowledge production, the Aboriginal Children's Survey (Canada 2006) was designed to collect data on the development of children from 0-5 years of age that would be comparable to data collected through the NLSCY. The 60-page survey was launched in 2006 as a response to the Communiqué on Early Childhood Development, signed in 2000 by the federal, territorial, and provincial governments (other than Quebec). Signatories agreed to use common performance benchmarks, with specific consideration to "newly developed indicators[,] such as [the] measure of the proportion of children ... ready to learn when they start school" (Canadian Intergovernmental Conference Secretariat 2000). "Ready to learn," of course, was a tip of the hat to the EDI, which by then included questions about Aboriginal status and language groups.

Like the CIS-2008, the Aboriginal Children's Survey also posed questions to participants concerning whether they or their spouse had 
been "a student at a federal residential school" (2006: 54), and if their children had ever been "removed or separated from [their] famil[ies] by child welfare agencies, church or government officials," how often, and for how long (44). Even though pitched as comparable to the NLSCY, which asked questions about alcohol and drug use, only the Aboriginal Children's Survey posed queries about whether a child had "Fetal Alcohol Syndrome, Fetal Alcohol Effect or Fetal Alcohol Spectrum Disorder" (16).

While more needs to be known about both the CIS-2008 and the Aboriginal Children's Survey regarding the assumptions driving the formulation of questions, how data were assessed, circulated, and so on, it is clear that these knowledge instruments reinforced the category of the Aboriginal child within an overall prevention and risk-assessment model.

It is important to point out that the creation of these national survey tools roughly coincided with the 10-year anniversary of the start of the EDI's creation in 1997. They marked the culmination of a decade that saw the broad acceptance of epigenetically-oriented early childhood ideas. While invisible to most observers, these mentalities had their basis, in part, on rhesus macaque studies, which had offered up a supposed scientific justification for involuntary child relinquishment. While more investigation is warranted into any apparent association, it is worth noting that this was the same decade, between 1997 and 2007, that saw a marked increase in the number of on-reserve Indigenous children in care (Canada 2008: 5; Sinha et al 2018: 17).

By the time the Aboriginal Children's Survey launched, the BC EDI project had been running since 2002, which was the same year that Mustard had wrapped up a report for the provincial government on how it could benefit from applying early childhood development ideas to public policy (Picherack and Mustard 2002). Around that time, the Province began providing full-funding to the HELP for pan-provincial EDI data collection, analysis and related activities. It also facilitated the HELP's research access to provincial government and independent schools for this purpose. Not long after, the province would ensure demand for EDI data by making vulnerability rates an official performance measure across departments (Murray 2015: 286).

With generous and long-term government commitments, the BC EDI project became a celebrated part of UBC's image as a global research leader. In 2005, the HELP drew the attention of the World Health Organization's Commission on the Social Determinants of Health. Headed by a Mustard associate, Michael Marmot, the Commission named the HELP the Global Knowledge Hub for Early Child Development (Einboden et 
al 2013: 551). The citation record of Mustard protégé, Clyde Hertzman, who headed the BC EDI project until his death in 2013, was said to be the highest in the field of health equity research for vulnerable populations (Canadian Institutes of Health Research 2011).

The Aboriginal category was a particular focus of concern for the BC EDI project. The HELP might have had some success in collecting data on Indigenous children who attended provincial schools, but it clearly faced difficulties collecting data from First Nations (Agreement 2011: 12-14; BC nda). On this point, it is important to note the distinction between provincial schools and First Nations' reserve schools. First Nations are self-governing as an inherent right. Over 10 years, only 30 percent of First Nations participated in the EDI (HELP ndb).

Though faced with difficulties in collecting data from First Nations communities, in the beginning, the HELP was quick to offer up interpretations of differences between vulnerability rates assessed with respect to the Aboriginal variable.

HELP's interpretative strategies for assessing Aboriginal EDI data aligned with the British Columbia Early Learning Framework ("Learning Framework") of which the BC EDI project was a part (BC 2008: 7). The framework rested on a principle of "social responsibility and respect for diversity" (33) through "a shared image of children ... as capable and full of potential[, and] as persons with complex identities, grounded in their individual strengths and capacities, and their unique social, linguistic, and cultural heritage" (4). Within this frame, the "process of social, economic and political transformation, as well as cultural and linguistic revitalization" (5) among First Nations was welcomed, in part, because a "First Nation's cosmology and world view" could be consistent with "children's responsibilities and rights" (33). In a similar vein, HELP analysts argued that low vulnerability rates found within Indigenous Peoples' communities gave "credence to [the] view" that "Aboriginal parenting styles and community traditions" could be "updated and restored" (Kershaw et al 2005: 63).

By 2011, public reporting on Aboriginal vulnerability ceased, no doubt, as a response to the First Nations Principles of Ownership, Control, Access and Possession ("OCAP"), which guided the use of information about Indigenous Peoples and their traditional knowledge. After that, EDI data results could be released only to "Chief and Councils and Aboriginal Education Councils" according to "strict guidelines" of HELP's Aboriginal Steering Committee (the "Steering Committee"), an entity that is discussed further below (HELP ndd; HELP nde).

We can see how these mentalities hinged upon a colonial logic by placing them in conversation with Coulthard's (2007) theorization of the 
"politics of recognition." The politics of recognition involves efforts to encourage "Indigenous [P]eoples to come to identify ... with profoundly asymmetrical and non-reciprocal forms of recognition either imposed on or granted to them by the colonial-state and society" (439, emphases in original), such as through attempts to "reconcile Indigenous claims to nationhood with Crown sovereignty via the accommodation of Indigenous identities in some form of renewed relationship with the Canadian state ..." (438).

We see such power asymmetries in how the Learning Framework construed diversity as a terrain of non-hierarchical and harmonious relations among groups with "distinct histories and contexts contribut[ing] to the rich social fabric of [the] province;" as well as how the framework fashioned diversity as a technique of "inclusion," whereby Indigenous children's presence in classrooms with settler-colonial students would be, among other things, a way to ensure that "young children experience[d] the [world's] cultural, ethnic, and linguistic diversity" (BC 2008: 6, 8). In these ways, settler-colonial violence was erased from view.

The politics of recognition also wove through the BC EDI project's data protocols that privileged the authority of the Province of British Columbia. This was apparent in the Province's oversight of the HELP's Aboriginal Steering Committee. Set up in 2003, the committee was to foster Aboriginal "community engagement" with the EDI (Agreement 2002: 39), to facilitate partnerships with First Nations and Métis, and to ensure that research would be "culturally sensitive and relevant" (HELP ndc). The committee membership (numbering 11 in 2018) included Indigenous Peoples working within the HELP's "overall vision" (HELP ndc; Rowcliffe 2018), as well as representatives from the provincial government serving in an ex-officio capacity (Agreement 2010: 13). Under explicit "reporting requirements," the HELP was to submit to the provincial government summaries of the steering committee's work, including information about which "First Nation schools ... did not participate in the EDI" (Agreement 2011: 14, 17; HELP ndb).

From a different perspective, contractually-defined data protocols potentially accorded the Province of British Columbia a right to access vulnerability rates for Aboriginal children in [the province] based on all available data" (Agreement 2011: 14, 16 - 17); HELP ndd and nde), as well as "reasonable" on-demand access to the full complement of the HELP's trove of information relating to the EDI project. The universitygovernment agreement expressly stated that

for contract monitoring and audit purposes, at all reasonable times, upon reasonable notice [the Government could] enter any premises used by the 
University to conduct the [EDI] Research Project or keep any documents or records pertaining to the Research Project, in order for the Province to inspect, audit, examine, review and copy any findings, data, specifications, drawings, working papers, reports, surveys, spread sheets, evaluations, documents, databases and other Material (both printed and electronic...) ... whether complete or not, that [were] produced, received or otherwise acquired as a result of this Agreement (2011: 4).

This hierarchically ordered but tight relationship between the government and the HELP was indecipherable in public relations materials (Agreement 2011: 4), obscured by a specific contractually-required phrase that the HELP was to use in its EDI publications, namely that it "acknowledged the financial support of the Province of British Columbia...."(Agreement 2010: 4). Given the apparent expansive data access contractually accorded to the Province of British Columbia, further inquiry is warranted to address the question of how the agreement's terms were communicated to First Nations in light of OCAP principles, as well as how these terms were operationalized.

The politics of recognition was also discernible over a third plane that the post-Delgamuukw context sharply brings forth. Delgamuukw v. British Columbia [1997] is a Supreme Court of Canada ruling that validated Indigenous Peoples' title where occupation was determined to be sufficient, continuous, and exclusive. The court did not define the source of proof, but it would self-evidently require mapping, for which the provincial government (BC 2013) and Indigenous Peoples were each separately engaged in apart from anything concerning the EDI (Hunt and Stevenson 2017). Importantly, in addition to mapping vulnerability rates, the HELP was obligated to map "Aboriginal Nation language group boundaries" (Agreement 2010: 13), which it did according to a guiding philosophy of "recogniz[ing] and respect[ing] the importance of language, culture, traditional land-ties and self-determination for Aboriginal communities" (HELP ndc). For the HELP, this information could be used to assess environmental circumstances shaping differential vulnerability rates. Questions need to be posed, however, about how the provincial government might have benefited from such maps beyond concerns with early childhood development, such as whether these maps might have had salience in land claims jurisprudence or in negotiating control over Indigenous children's welfare.

In this vignette, we have seen how the figure of the at-risk Aboriginal child was discovered, that is shaped and moulded through knowledge instruments, including the EDI as a mediating device for the epigenetic style of thought. Through the genealogical lens, a politics of recognition orientation has been made audible, specifically concerning how EDI 
mediations positioned the provincial government to bestow acknowledgement on Indigenous Peoples' communities on epigenetic terms and in ways that aligned with settler-colonial authorities' priorities. While First Nations overwhelming refused the EDI survey process, refusals did not take away from attempts to secure the gaze. And value would be generated, not only as data was collected and assessed and mapped, but also as questions were addressed about how to extend the EDI, how to hone it, how to expand it, and so on. Meanwhile, the very real inequities shaping the lives of many Indigenous children were being turned into grist for the vulnerability mill according to normative assumptions about parenting and places which in a myriad of ways hinged on problematic images of Indigenous parents, especially mothers.

\section{Governing through the Vulnerable Aboriginal Child}

An archaeological lens on the Province of British Columbia's StrongStart BC program brings into view how EDI mediations intersected with street-level dynamics in particular ways concerning the classification of the vulnerable Aboriginal child. Five years after launching in 2006, more than 300 StrongStarts were operating. Most were set up in provincial schools. Some were mobile units. By 2011, upwards of a half a million children and parents had participated in the program (BC 2011a). StrongStarts were government funded and under the purview of the political executive, which controlled all aspects of the program, including the use of "graphics, news releases and announcements" (BC 2009a).

The government pitched the program as a no-cost, voluntary, "playbased early learning...drop-in ... [to] prepare children for success in Kindergarten" (BC ndb). The government made clear that the program was not "designated child care" (BC 2009b), for instance, to support working parents. Each child had to be accompanied by a parent/caregiver ("parent"). Parents had to show identification (such as an "Aboriginal Status Card") and to "sign in and out everyday that [they] attend[ed]" (BC 2011b). Even with its formal aspects, for participants, StrongStart would no doubt have had the touch and feel of informality, particularly since this non-academic program "include[d] stories, music and art" (BC $\mathrm{ndb}$; BC 2007).

StrongStart's administrative practices included efforts to align individual ways of being to epigenetic norms, processes that presumed that children and their parents were lacking or potentially so. For children's minds, the program promoted "impulse control," as well as "self-discipline, responsibility, positive capabilities and attitudes" (West Langley 
Elementary 2013). For their bodies, activities included "large muscle" movements and access to proper nutrition, such as "healthy snacks" (BC ndc: 3, 36, 47; HELP and BC 2008: 35). And, for the children's souls, tasks included nurturing "exploration and creativity" (BC ndc: 36). For the parents, front-line staff were encouraged, among other things, to model "ways to support learning" (1) and to describe "the learning that [was] occurring in the moment" (26). In some cases, parents would be included in "the regular cleaning of toys" (15). Determinations would also be made about whether a parent should be directed to other agencies, such as when FAD were suspected (BC ndc: 15, 33, 36; HELP and BC 2007; HELP and BC 2008: 60).

Questions arise about StrongStarts' potentially coercive features when connections are made between disparate program elements. One element concerns direct and indirect profiling of "the vulnerable." According to a program evaluation published in 2007 by the HELP in conjunction with the Province of British Columbia, most of the initial StrongStart sites were located in "low socio-economic area[s] ... with a large [immigrant] population or [with] a high percentage of Aboriginal students" (HELP and BC 2007: 14). A follow up report, in 2008, recommended that StrongStart administrators assess "local demographics," that they "monitor who [was] (and was not)" participating, and that they make a "genuine effort" to figure out how to make the program appealing to the hard-to-serve, including low-income people, "refugees[,] immigrants and Aboriginal populations." It was further advised that street-level administrators foster partnerships "with local Aboriginal leaders" and be "sensitive to Aboriginal culture" (HELP and BC 2008: $60)$. This evaluation lauded "creative strategies to encourage the attendance of vulnerable families," such as sending taxis to "pick up remote families," and, as happened in one case, knocking "on doors ... [to look] for preschoolers" (HELP and BC 2008: iii, 22, 35; see also HELP and BC 2007: 32). The latter was a clear instance of how StrongStart served as a milieu for provincial government authority to reach directly into lives of families profiled as vulnerable on epigenetic terms. Profiling was reinforced in the program's half-day operating hours (BC ndc: 66; BC 2009b), which would have been more amenable to schedules of people who were unemployed, a category overrepresented by Census-defined lone mothers. Within the lone mother category, Indigenous mothers, often structurally excluded from labour markets, were known to have higher unemployment rates than non-Indigenous mothers (Canada 2012: 23).

The potential implications of profiling practices need further consideration in relation to Personal Education Numbers ("PENs"). Here, 
I will highlight a few aspects that might direct future research. Under the School Act (1996), the government assigned a PEN to every child entering the provincial school system, as well as to children in First Nation schools that had a Reciprocal Tuition Agreement, whereby the Provincial Government would provide "per-pupil funding...for school-age students living off-reserve who [were] enrolled in First Nations schools, and for eligible non-status students living on reserve lands" (First Nations Schools Association \& First Nations Education Steering Committee 2013: 3-4).

While serving a variety of purposes, PENs would make it possible to turn StrongStart participants into a control group for evaluating early learning interventions (Agreement 2008: 4; BC ndd; BC nde: 18; Offord Centre for Child Studies 2016e). Being able to identify children who had participated in StrongStart for research purposes would align with the HELP's contractual duty to "[c]onduct research on children who [were] developmentally vulnerable due to biological, medical[, or] environmental factors" (Agreement 2008: Schedule A). The agreement between the provincial government and the university expressly stated that the HELP was to "ensure data [was] complete, ready for analysis, and linkable to other data sources," including PENs (Agreement 2011: 12). Other named datasets dovetailed with concerns that had underpinned the meaning and practice of "child welfare" as it had surfaced since the 1990s, such as the "children-in-care database and the child injury file" (Agreement 2002: 10; Agreement 2008: 4), as well as the BC Linked Health Database. The BC Perinatal Register, part of the latter (Agreement 2002: 9, 10; Agreement 2006: 10), maintained information on maternal mental health, as well as drug and alcohol use during pregnancy (Population Data BC 2016 and 2017). By 2011, the HELP had linked PENs to "94 percent of EDI assessments carried out between 2000 and 2005," in addition to linking "97 percent of PENs to a Personal Health Number (making it possible to merge health, education, and developmental information)." HELP had also "created a physical infrastructure ... to link birth, physician and hospital services [to the] EDI ... on a person-specific ... but anonymous basis" (Hertzman 2011c: 227). All of these data were amenable to a host of different types of assessments, geographical and otherwise, including according to Aboriginal status indicators. 


\section{Table 1}

\begin{tabular}{|l|l|}
\hline \multicolumn{2}{|l|}{\begin{tabular}{l} 
Comparison of Terminology: British Columbia's Legal Duty to Report and the \\
Early Development Instrument \\
\hline \multicolumn{1}{|c|}{ Duty to Report }
\end{tabular}} \\
\hline Severe anxiety & EDI \\
\hline Severe depression & Unhappy, sad or depressed \\
\hline Severe withdrawal & Shy/worried \\
\hline Self-destructive behavior & Demonstrates self-control/self-confident \\
\hline Aggressive behavior & Bullies or is mean to others \\
\hline
\end{tabular}

Source: Compiled from Child, Family and Community Service Act [RSBC 1996] Chapter 46, Sections 13 and 14; and McMaster University (2000).

Against this backdrop, questions need to be raised about the intersecting dynamics running through profiling practices, PENs, EDI data extractions and analyses, and the legal duty to report. We can begin by providing a preliminary sketch of key issues, starting with the duty to report, which would be a legal obligation regardless of whether "the information on which the belief [of harm was] based ... [were] privileged" (other than solicitor-client privilege) or "confidential and its disclosure ... prohibited under another Act" (Child, Family and Community Service Act [RSBC 1996]: 14.2.a and 14.2.b). This obligation raises the question of whether mandated reporting might be feasible based on evaluations of anonymized data, including EDI data. HELP emphasized that it would only use EDI data in population-level analyses (Schonert-Reichl 2017: 2), but it acknowledged that "[r]e-identification" was a potential; and, it expressed a commitment to "safeguarding personal information" as a priority (HELP ndf and ndg). The HELP committed to transparency in its intent to provide individualized and linkable data to the Province (Agreement 2010: 13), and the consent form that it provided to parents said that the government would "never be using [EDI] data to evaluate any child individually" (Schonert-Reichl 2017: 2). Even with these assurances, questions about the duty to report's potential within the BC EDI project remain. 
Additional questions arise from the fact that parts of EDI included terminology with a family resemblance to mandated reporting provisions in the Child, Family and Community Service Act (1996), as illustrated in Table 1 . Setting aside the matter of de-anonymizing data, the very close alignment between these lexicons needs to be considered with respect to kindergarten teachers' EDI assessments, such as whether any skewed reporting patterns resulted, namely over-reporting. Such questions are especially crucial to pose in light of profiling of "the vulnerable," as well as the relationship of such profiling to governance practices. StrongStart participants were not, at the outset, accused of criminal conduct, but through profiling there was arguably a measure of doubt about their parenting ability. In this way, StrongStart operated in some sense as a site through which the lines between freedom and control were governmentally negotiated, with the EDI a key instrument in mediating these horizons. When viewed through the lens of the colonial present and the singular importance of the at-risk Aboriginal child category, questions need to be asked about possible ramifications relating to Indigenous Peoples' jurisdiction over their children and territories.

\section{Conclusion}

This article has focused on the settler-colonial context of Canada to illustrate how an epigenetic style of thought was mediated through the Early Development Instrument in ways that shaped the classification of the vulnerable Aboriginal child as a terrain of settler-colonial power. By doing so, the article makes four theoretical contributions.

First, the article shows that there will be blind spots in our comprehension of the political elements of epigenetics if it is assumed that the word "epigenetics" is exclusively constitutive of the epigenetic style of thought. As Muller et al (2017: 1678) have emphasized, "the influence of the environment on phenotype is not a new proposition or radical new perspective in biology." As has been illustrated, in Canada, epigenetic reason shaped a way of seeing and acting upon child development long before the word epigenetics surfaced as a new lingua franca of governance. Second, the article demonstrates the epigenetic style of thought needs to be considered as more than a population management tool. The context of the colonial present underscores how population management and territorial control are closely intertwined elements that need to be evaluated in relation to political jurisdiction. Third, through an archeological assessment of StrongStart, the study underscores the necessity of documenting the political implications flowing through often obscure 
administrative-legal relationships, practices, and elements shaped in significant ways by epigenetic reason. Nowhere was this more obvious than in the contextually specific questions arising from how the EDI was tied to StrongStart's systems of professional judgement, regulation, and attendant possibilities for forced relinquishment of children, all of which pointed towards specific implications for Indigenous Peoples' jurisdiction over their children and territories.

A fourth way that this assessment extends debates about the relationship between epigenetics and politics is visible in the context of the Liberal Government of Justin Trudeau's response to the officially declared "humanitarian crisis" of the astoundingly high numbers of Indigenous children in the "child protection" system (Barrera 2017). In 2018, the government offered a six-point plan that called for, among other things, "prevention and early intervention" (Canada 2018). Such language echoed the lexicon heard over a quarter-century in child development discourses grounded in the epigenetic style of thought. As we have seen, this lexicon was bound up with capitalist, colonialist, and eugenicist dynamics that shaped and were shaped by the category of the vulnerable Aboriginal child as it was mediated via the EDI. From this vantage, the ringing silence that defines the almost complete absence of attention on the colonial present within critical assessments of the political elements of epigenetics is more than an empirical and theoretical flaw perpetuating colonial injustices. Making these power relations audible will allow for a deeper appreciation of what is at stake in new and emerging policy commitments that might also traverse the linkages between epigenetics and politics.

"Justice," Michel Foucault said, "must always question itself, just as society can exist only by means of the work it does on itself and on its institutions" (as quoted in Words of Justice nd). It could not be more urgent to be documenting, questioning and theorizing the full extent of the links between epigenetics and politics in the colonial present. In Canada, almost every province and territory was in some way using the EDI by the end of the millennium's first decade. Worldwide, more than 30 other countries across the Global North and South were using the EDI in some fashion (Offord Centre for Child Studies 2016b), many also entangled in colonialist relationships. It is vital to include EDI mediations in discussions about the political elements of epigenetics, as well as to place them in a global context. Engaging the birthplace of the EDI in conversation with the world is one place to start. 


\section{REFERENCES}

Access to Information Act [R.S.C. 1985 c. A-1].

Agreement between Her Majesty the Queen in Right of the Province of British Columbia, represented by the Minister of Children and Family Development and the University of British Columbia, April 1, 2002. Contract XLR2035118. Obtained under FOIPPA, JAG-201-00601.

Agreement between Her Majesty the Queen in Right of the Province of British Columbia, represented by the Minister of Children and Family Development and the University of British Columbia, April 1, 2006. Contract XLR2065000. Obtained under FOIPPA, JAG-201-00601.

Agreement [Modification] between Her Majesty the Queen in Right of the Province of British Columbia, represented by the Minister of Children and Family Development and the University of British Columbia, Schedule A, April 1, 2008. Contract XLR2065000. Obtained under FOIPPA, JAG-201-00601.

Agreement between Her Majesty the Queen in Right of the Province of British Columbia, represented by the Minister of Children and Family Development and the University of British Columbia, September 1, 2010. Contract \#XCE192393. Obtained under FOIPPA, JAG-201-00601.

Agreement between Her Majesty the Queen in Right of the Province of British Columbia, represented by the Minister of Children and Family Development and the University of British Columbia, September 1, 2011. Contract \#XCE201082. Obtained under FOIPPA, JAG-201-00601.

Alfred, Taiaiake and Jeff Corntassel. 2005. Being Indigenous: Resurgences against contemporary colonialism. Government and Opposition 40(4):597-614.

An Act to Amend and Consolidate the Laws Respecting Indians, Statutes of Canada 1876, Chapter 18.

Anglin, James P. 2002. Risk, well-being, and paramountcy in child protection: The need for transformation. Child \& Youth Care Forum 31(4): 233-255.

Armstrong, E. M. 2003. Conceiving Risk, Bearing Responsibility: Fetal Alcohol Syndrome and the Diagnosis of Moral Disorder. Baltimore: The John Hopkins Press.

Barrera, Jorge. 2017. Indigenous child welfare rates creating "humanitarian crisis" in Canada, says federal minister. CBC News, November 2 http://www.cbc.ca/ news/indigenous/crisis-philpott-child-welfare-1.4385136 (access date: May $15,2018)$.

Blackstock, Cindy. 2003. First Nations child and family services: Restoring peace and harmony in First Nations communities. In Child Welfare: Connecting Research, Policy, and Practice, edited by Kathleen Kufeldt and Brad McKenzie, 331-342. Waterloo: Wilfrid Laurier University Press.

Blackstock, Cindy. 2015. Should governments be above the law? The Canadian Human Rights Tribunal on First Nations child welfare. Children Australia 40(2):95-103. 
Boyd, Susan C. 1999. Mothers and Illicit Drugs: Transcending the Myths. Toronto: University of Toronto Press.

British Columbia. nda. First Nations Schools. Victoria: Ministry of Education. https:// www2.gov.bc.ca/gov/content/education-training/administration/kindergarten-to-grade-12/aboriginal-education/first-nations-schools (access date: May 4, 2018).

British Columbia. ndb. Find a StrongStart BC Centre. Victoria: Ministry of Education. https://www2.gov.bc.ca/gov/content/education-training/early-learning/ learn/strongstart-bc (access date: May 6, 2018).

British Columbia. ndc. StrongStart BC: Early Learning Programs. Operations Guide. Victoria: Ministry of Education. https://www2.gov.bc.ca/gov/content/education-training/administration/kindergarten-to-grade-12/early-learning/strongstart-bc (access date: November 6, 2018).

British Columbia. ndd. PEN protocol. Victoria: Ministry of Education. https://web. archive.org/web/20080501142009/http://www.bced.gov.bc.ca/pen/protocol. htm (access date: August 6, 2018).

British Columbia. nde. Early Years in BC School Districts: A Scan of Promising Practices. Victoria: Provincial Office for the Early Years. https://www2.gov.bc.ca/ assets/gov/family-and-social-supports/child-care/early years in sd promising_practices.pdf (access date: August 19, 2018).

British Columbia. 2007. Sample StrongStart BC poster: Conrad StrongStart Centre. Victoria: Ministry of Education. https://web.archive.org/ web/20130515002110/http://www.bced.gov.bc.ca/early_learning/pdfs/conrad_ss_poster.pdf (access date: August 3, 2018).

British Columbia. 2008. British Columbia Early Learning Framework. Victoria: Ministry of Health and the Ministry of Children and Family Development. https://www2.gov.bc.ca/gov/content/education-training/early-learning/teach/ early-learning-framework (access date: August 6, 2018).

British Columbia. 2009a [Revised May 17, 2017]. Strong Start BC early learning outreach programs. Ministry of Education. https://www2.gov.bc.ca/gov/content/ education-training/administration/legislation-policy/public-schools/strongstart-bc-early-learning-outreach-programs (access date: August 6, 2018).

British Columbia. 2009b. Policy Document: StrongStart BC Early Learning Centre. Revised policy. Victoria: Ministry of Education. https://web.archive.org/ web/20110826051703/http://www.bced.gov.bc.ca/policy/policies/strong start.htm (access date: August 19, 2018).

British Columbia. 2011a. Revised 2011/12-2013/14 Service Plan. Victoria: Ministry of Education. http://bcbudget.gov.bc.ca/2011/sp/pdf/ministry/educ.pdf (access date: April 8, 2018).

British Columbia. 2011b. Tips for parents/caregivers attending a StrongStart BC program. Victoria: Ministry of Education. https://web.archive.org/ web/20111223144917/http://www.bced.gov.bc.ca/early_learning/strongstart bc/tips.htm (access date: August 10, 2018). 
British Columbia. 2013. (Revised). High Bar First Nation: Llenlleney’Ten. Review of Ethnographica and Historical Sources, November 18, Ministry of Justice. FOIPPA, JAG-2017-71538.

British Columbia and Child and Youth Officer for British Columbia. 2006. Joint Special Report: Health and Well-being of Children in Care in British Columbia: Report 1 on Health Services Utilization. Victoria, BC. http://cwrp.ca/sites/ default/files/publications/en/BC-Children in CareReport1.pdf (access date: August 9, 2018).

British Columbia Assembly of First Nations. 2018. Honouring our ancestors. http:// bcafn.ca/ (access date: October 9,2018).

Brown, Wendy. 2015. Undoing the Demos: Neoliberalism's Stealth Revolution. New York: Zone Books.

Canada. 2006. Aboriginal Children's Survey 2006 (Children - aged 0 to 5). Ottawa: Statistics Canada. http://www23.statcan.gc.ca/imdb-bmdi/instrument/5108 Q2 V1-eng.pdf (access date: November 16, 2017.

Canada. 2008. Report of the Auditor General of Canada to the House of Commons. Ottawa: Minister of Public Works and Government Services Canada. http:// www.oag-bvg.gc.ca/internet/docs/aud_ch_oag_200805 04_e.pdf

(access date: March 25, 2018).

Canada. 2012. Aboriginal Women in Canada: A Statistical Profile from the 2006 Census. Ottawa: Aboriginal Affairs and Northern Development Canada. https:// www.aadnc-aandc.gc.ca/DAM/DAM-INTER-HQ/STAGING/texte-text/ ai_rs_pubs_ex_abwch_pdf_1333374752380_eng.pdf (access date: August $18,2018)$.

Canada. 2018. Federal government commits to six points of action in working with Indigenous partners to address number of Indigenous children in care. News Release, January 26. Ottawa: Indigenous Services Canada. https://www.canada.ca/en/indigenous-services-canada/news/2018/01/federal governmentcommitstosixpointsofactioninworkingwithindigen.html (access date: April 30, 2018).

Canadian Association of University Teachers. 2018. Guide to acknowledging First Peoples and traditional territory.

Canadian Child Welfare Research Portal. 2011a. CIS overview. http://cwrp.ca/overview (access date: May 20, 2018).

Canadian Child Welfare Research Portal. 2011b. The First Nations component of the Canadian Incidence Study of Reported Child Abuse and Neglect. http://cwrp.

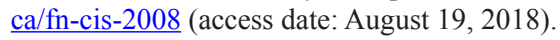

Canadian Incidence Study of Reported Child Abuse and Neglect. 2008. Available at Canadian Child Welfare Research Portal. http://cwrp.ca/sites/default/files/ publications/en/CIS-2008 Maltreatment_Assessment_FINAL.pdf (access date: August 19, 2018). 
Canadian Institutes for Advanced Research. 1992. The Learning Society. Toronto: Canadian Institutes for Advanced Research. https://archive.org/details/ ERIC ED372822 (access date: November 18, 2017).

Canadian Institutes of Health Research. 2011. Internal assessment for 2011 international review - CIHR Institute of Population and Public Health. http:// www.cihr-irsc.gc.ca/e/43679.html (access date: May 9, 2018).

Canadian Intergovernmental Conference Secretariat. 2000. First Ministers' Meeting Communiqué on Early Childhood Development. Ref. 800-038/005. September 11. Available at Human Resources and Skills Development, Early Childhood Development, Ottawa. http://www.ecd-elcc.ca/eng/ecd/ecd_communique shtml (access date: May 3, 2018).

Chiappetta, Margaret and Kean Birch. 2018. Limits to biocapital. In Handbook of Genomics, Health and Society, second edition, edited by Sahra Gibbon, Barbara Prainsack, Stephen Hilgartner and Janelle Lamoreaux, 63-70. London and New York: Routledge.

Child, Family and Community Service Act [RSBC 1996] Chapter 46. http://www. bclaws.ca/civix/document/id/complete/statreg/96046 01 (access date: June 11, 2012).

Constitution Act, 1982, being Schedule B to the Canada Act 1982 (UK), c 11.

Coulthard, Glen. 2007. Subjects of empire: Indigenous Peoples and the "politics of recognition" in Canada. Contemporary Political Theory 6:437-460.

Coulthard, Glen. 2014. Red Skins, White Masks: Rejecting the Colonial Politics of Recognition. Minnesota: University of Minnesota Press. Digital.

Coulthard, Glen. 2015. The colonialism of the present: An interview with Glen Couthard. Jacobin, January 13 https://www.jacobinmag.com/2015/01/indigenous-left-glen-coulthard-interview/ (access date: May 13, 2018).

de Leeuw, Sarah. 2014. State of care: The ontologies of child welfare in British Columbia. Cultural Geographies 21(1):59-78.

de Leeuw, Sarah and Sarah Hunt. 2018. Unsettling decolonizing geographies. Geography Compass. https://doi.org/10.1111/gec3.12376

Delgamuukw v. British Columbia (1997) 3 S.C. R 1010.

Elden, Stuart. 2013a. Secure the volume: Vertical geopolitics and the depth of power. Political Geography 34(A-1-A4):35-51

Elden, Stuart. 2013b. How should we do the history of territory? Territory, Politics, Governance 1(1):5-20.

Einboden, Rochelle, Trudy Rudge and Colleen Varcoe. 2013. Producing children in the $21^{\text {st }}$ century: A critical discourse analysis of the science and techniques of monitoring early child development. Health 17(6):549-66. 
First Nations Schools Association \& First Nations Education Steering Committee. 2013. Reciprocal Tuition Handbook for Non-independent First Nations Schools. Vancouver: First Nations Schools Association \& First Nations Education Steering Committee. http://www.fnsa.ca/wordpress/wp-content/ uploads/2013/08/Reciprocal-Tuition-Information-Handbook-FINAL-August-19.pdf

Foucault, Michel. 1972. The Archeology of Knowledge and the Discourse on Language, translated by. A.M. Sheridan. New York: Vintage Books.

Foucault, Michel. 1979. Discipline \& Punish: The Birth of the Prison, translated by Alan Sheridan. New York: Vintage Books.

Freedom of Information and Protection of Privacy Act [RSBC 1996] Chapter 65.

Fuchs, Don. 1994. Summary of presentation entitled: Neighbourhood parent support: An effective resource for the prevention of child abuse. In Winnipeg's Inner City: Current and Future Research Directions Workshop Proceedings, edited by Catherine Charette, 45-57, Winnipeg. University of Winnipeg: Institute of Urban Studies.

Fuchs, Don and Don Lugtig. 1989. Prevention of child maltreatment in high risk multi-ethnic and multi-cultural neighbourhoods. Winnipeg. University of Manitoba, School of Social Work.

Garbarino, James. 1980. What kind of society permits child abuse? Infant and Mental Health Journal 1(4):270-280.

Garbarino, James. 1995. Raising Children in a Socially Toxic Environment. San Francisco: Jossey-Bass Publishers.

Garbarino, James and Kathleen Kostelny. 1994. Neighbourhood based programs. In Protecting Children from Abuse and Neglect: Foundations for a New National Strategy, edited by Gary B. Melton and Frank D. Barry, 304-352. New York: Guildford Press.

Garbarino, J. and D. Sherman. 1980. High-risk neighbourhoods and high-risk families: The human ecology of child maltreatment. Child Development 51(1):188-98

Geary, Aidan. 2018. "It's illegal and it has to stop": Child welfare agencies file affidavit in court case against province. $C B C$ News, July 24 . https://www.cbc. $\mathrm{ca} /$ news/canada/manitoba/manitoba-indigenous-child-welfare-agencies-lawsuit-1.4758982 (access date: November 7, 2018).

Gillies, Val, Rosalind Edwards, and Nicola Horsley. 2017. Challenging the Politics of Early Intervention: Who's "Saving" Children and Why. Bristol: Policy Press. Digital.

Gove, T. J. 1995. Report of the Gove Inquiry into Child Protection. Victoria: Queen's Printer. http://www.qp.gov.bc.ca/gove/govevol2.htm (access date: August 8, 2018).

Grant, Isabel, Judith Mosoff, Susan B. Boyd and Ruben Lindy. 2017. Intersecting challenges: Mothers and child protection law in BC. UBC Law Review 50(2):435-504. 
Greaves, Lorraine, Colleen Varcoe, Nancy Poole, Marina Morrow, Joy Johnson, Ann Pedersen, and Lori Irwin. 2002. A Motherhood Issue: Discourses on Mothering Under Duress. Ottawa: Status of Women Canada.

Hayes, Michael V. and James R. Dunn. 1998. Population Health in Canada: A Systematic Review. Canadian Policy Research Network Study No. HI01I. Ottawa: Renouf Publishing Co. Ltd.

Hedlund, Maria. 2012. Epigenetic responsibility. Medicine Studies 3:171-183.

HELP. nda. Social epigenetics. Vancouver. University of British Columbia. http:// earlylearning.ubc.ca/biology/social-epigenetics/ (access date: May 12 2018).

HELP. ndb. The EDI: An Aboriginal perspective. Vancouver. University of British Columbia. http://earlylearning.ubc.ca/edi/aboriginal-EDI/ (access date: May 5, 2018).

HELP. ndc. Aboriginal engagement. http://earlylearning.ubc.ca/about/aboriginalcommunity-engagement/. Vancouver. University of British Columbia (access date: April 13, 2018).

HELP. ndd. The early development instrument: Aboriginal data, Chief and Councils and Aboriginal Education Councils. Vancouver. University of British Columbia. http://earlylearning.ubc.ca/media/publications/access to aboriginal data_info_card_2015.pdf (access date: April 8, 2018).

HELP. nde. The Early Development Instrument: Aboriginal data. Vancouver. University of British Columbia. http://earlylearning.ubc.ca/media/publications/ access to aboriginal_data_info_card_2015.pdf (access date: April 12, 2018).

HELP. ndf. Safeguarding personal information. Vancouver. University of British Columbia. http://earlylearning.ubc.ca/safeguarding-personal-information/ (access date: May 5, 2018).

HELP. ndg. Mapping and Aboriginal data. http://earlylearning.ubc.ca/maps/mappingaboriginal-data/. (access date: August 20, 2018).

HELP. 2018. EDI BC: 2016 provincial report. Vancouver. University of British Columbia. http://www.edibc2016.ca (access date: May 11, 2018).

HELP and British Columbia. 2007. Evaluation of StrongStart BC. School-based (Preschool) Family Drop-in Centres: Stage 1. Vancouver and Victoria. University of British Columbia and Province of British Columbia. https://www2.gov. bc.ca/assets/gov/education/.../strongstart/strongstart eval_stage1.pdf// access date: November 6, 2018).

HELP and British Columbia. 2008. Evaluation: StrongStart BC. School-based (Preschool) Family Drop-in Centres. Vancouver and Victoria. University of British Columbia and Province of British Columbia. Retrieved from Internet Archive Wayback Machine. http://www.bced.gov.bc.ca/early learning/pdfs/ strongstart evaluation report.pdf (access date: November 6, 2018).

Hertzman, Clyde. 1999 The biological embedding of early experience and its effects on health in adulthood. Annals of the New York Academy of Sciences 896: 85-95. 
Hertzman, Clyde. 2011a. Ten years of insight: Connecting the dots. Vancouver: Human Early Learning Partnership. https://www.youtube.com/ watch? feature $=$ player embedded $\& v=$ kpjdHwvaHWQ (access date: May 21, 2018).

Hertzman, Clyde. 2011b. Investing in our children, investing in our future, transcript of presentation at the Australian Institute for Social Research, Adelaide, Australia, September 2011. http://www.adelaide.edu.au/wiser/docs/Clyde_Hertzman_Transcription.pdf (access date: May 8, 2013).

Hertzman, Clyde. 2011c. Bringing a population health perspective to early biodevelopment: An emerging approach. In Nature and Nurture in Early Childhood Development, edited by Daniel Keating, 217-245. Cambridge: Cambridge University Press.

Hunt, Dallas and Shaun A. Stevenson. 2017. Decolonizing geographies of power: Indigenous digital counter-mapping practices on Turtle Island. Settler Colonial Studies 7(3):372-392.

Hunter, Justine. 2018. B.C.'s new child protection law includes Indigenous communities as decision makers. The Globe and Mail, April 24. https://www.theglobeandmail.com/canada/british-columbia/article-bcs-new-child-protectionlaw-includes-indigenous-communities-as/ (access date: August 21, 2018).

Jacobs, Eva. 1992. Liberating Our Children - Liberating Our Nation. Community Panel Child Protection Legislative Review. British Columbia. Ministry of Social Services. Report of the Aboriginal Committee. http://www.turtleisland. org/healing/liberate.html (access date: March 20, 2018).

Janus, Magdalena. 2006a. Measuring community early child development. Canadian Association of Principals Journal 14(3):1-4. https://edi.offordcentre.com/ wp/wp-content/uploads/2015/06/PUB.9.2006_Janus.pdf (access date: May $15,2018)$.

Janus, Magdalena. 2006b. The Early Development Instrument ... national and international perspectives. http://www.excellence-jeunesenfants.ca/documents/ Janus1_posterANG.pdf (access date: April 17, 2018).

Janus, Magdalena, Sally Brinkman, Eric Duku, Clyde Hertzman, Robert Santos, Mary Sayers and Joanne Schroeder. 2007. The Early Development Instrument: Population-based Measure for Communities. Hamilton: McMaster University. http://www.manitoba.ca/healthychild/edi/edi_handbook_2007. pdf (access date: April 17, 2018).

Janus, Magdalena and David Offord. 2007. Development and psychometric properties of the Early Development Instrument (EDI): A measure of children's school readiness. Canadian Journal of Behavioural Science, 39(1):1-22.

Juengst, Eric T., Jennifer R. Fishman, Michelle L. McGowan, and Richard A. Settersen Jr. 2014. Serving epigenetics before its time. Trends in Genetics 30(10):427-429. 
Justice Education Society and Centre for Education, Law, and Society. 2017. Native land claims - Backgrounder. Vancouver. Simon Fraser University. http:// www.lawconnection.ca/content/native-land-claims-backgrounder (access date: April 13, 2018).

Keating, Daniel P. and J. F. Mustard. 1993. Social economic factors and human development. In Family Security in Insecure Times, edited by D. Ross, 87-105. Ottawa: National Forum on Family Security.

Keller, Evelyn Fox. 2014. From gene to action to reactive genomes. The Journal of Physiology, 592(Pt 11):2423-2429.

Kempe, C. H., F. N. Silverman, B.F. Steele, W. Droegemueller, and H. K. Silver. 1962. The battered-child syndrome. Child Abuse \& Neglect 9:143-154.

Kendall, Gavin and Gary Wickham. 2003. Using Foucault's Methods. London: Sage.

Kenney, Martha and Ruth Müller. 2017. Of rats and women: Narratives of motherhood in environmental epigenetics. Biosocieties 12(1):23-46.

Kenney-Wallace, Geraldine A. and J. Fraser Mustard. 1988. From paradox to paradigm: The evolution of science and technology in Canada. Daedalus, 117(4):191-214.

Kershaw, Paul, Lori Irwin, Kate Trafford, and Clyde Hertzman. 2005. The British Columbia Atlas of Child Development, $1^{\text {st }}$ edition. Vancouver: Human Early Partnership and Western Geographical Press.

Kline, M. 1992. Child welfare law, 'best interests of the child' ideology, and First Nations. Osgoode Hall Law Journal 30(2):375-425.

Kline, M. 1994. The colour of law: Ideological representations of First Nations in legal discourse. Social and Legal Studies 3:451-476.

Lugtig, Don and Don Fuchs. 1992. Building on the Strengths of Local Neighbourhood Social Network Ties for the Prevention of Child Maltreatment: The Final Report of the Neighbourhood Parent Support Project. Winnipeg. University of Manitoba. Child and Family Research Group, Faculty of Socail Work.

Mansfield, B. 2012. Race and the new epigenetic biopolitics of environmental health. Biosocieties 7(4):352-372.

Mansfield, B. and J. Guthman. 2015. Epigenetic life: Biological plasticity, abnormality, and new configurations of race and reproduction. Cultural Geographies 22(1):3-20.

Mathews, Ben and Maureen C. Kenny. 2008. Mandatory reporting legislation in the United States, Canada, and Australia: A cross-jurisdictional review of key features, differences and issues. Child Maltreatment 13(1):50-63.

McCain, Margaret and J. Fraser Mustard. 1999. Reversing the Real Brain Drain: Early Years Study. Final Report. Toronto: Canadian Institute for Advanced Research and the Founders' Network for the Ontario Children's Secretariat. 
McMaster University. 2000. 2017/2018. Early Development Instrument: A Population-Based Measure for Communities. British Columbia, 2017/2018. Hamilton, Ontario. http://earlylearning.ubc.ca/media/edi_offord_2017_2018.pdf (access date: May 11, 2018).

McMaster University. 2009. Lecture named for McMaster Medical School pioneer, March 31. http://fhs.mcmaster.ca/main/news/news_2009/mustard_lecture named.html (access date: May 29, 2013).

Meloni, M. 2016. Political Biology: Science and Social Values in Human Heredity from Eugenics to Epigenetics. New York and Basingstoke, UK: Palgrave Macmillan. Digital.

Meloni, Maurizio. 2017. Race in an epigenetic time: Thinking biology in the plural. The British Journal of Sociology 68(3):389-409.

Meloni, Maurizio and Giuseppe Testa. 2014. Scrutinizing the epigenetics revolution. BioSocieties 9(4):431-456.

Monture, Patricia. 1989. A vicious circle: Child welfare and the First Nations. Canadian Journal of Women and the Law 3:1-17.

Müller, Ruth, Clare Hanson, Mark Hanson, Michael Penkler, Georgia Samaras, Luca Chiapperino, John Dupré, Martha Kenney, Christopher Kuzawa, Joanna Latimer, Stephanie Lloyd, Astrid Lunkes, Molly Macdonald, Maurizio Meloni, Brigitte Nerlich, Francesco Panese, Martyn Pickersgill, Sarah Richardson, Joëlle Rüegg, Sigrid Schmitz, Aleksandra Stelmach, Paula-Irine Villa. 2017. The biosocial genome? Science \& Society 18(1):1677-1682.

Murray, Karen Bridget. 2007. Governmentality and the shifting winds of policy studies. Critical Public Policy: Canadian Perspectives, edited by Miriam Smith and Michael Orsini, 161-184. Vancouver: UBC Press.

Murray, Karen Bridget. 2015. Bio-gentrification: Vulnerability bio-value chains in gentrifying neighbourhoods. Urban Geography 36(2):277-299.

Murray, Karen Bridget. 2017. The violence within: Canadian modern statehood and the pan-territorial residential school system ideal. Canadian Journal of Political Science 50(3):747-772.

Mustard, J. Fraser. 2000. Early child development: The base for a learning society. Presentation to a join meeting of Human Resources Development Canada and the Organization for Economic Co-operation and Development. Ottawa. December 7. http://www.oecd.org/education/school/31551283.pdf (access date: July 29, 2018).

Mustard, J. Fraser. 2009. Early human development - equity from the start. Revista Latinamericana de Ciencias Sociales, Ninez y Juventud 7 (2):639-680.

Mustard, J. Fraser. 2010. Early human development and later development. Presentation at Equity from the Start: 10 years of the EDI and beyond. Hamilton, Ontario, June 16. http://www.offordcentre.com/conference/edi video.html (access date: May 28, 2013). 
National Longitudinal Survey of Children and Youth. 2011. Detailed information for 2008-2009 (Cycle 8). Ottawa: Statistics Canada. http://www.statcan.ca/cgibin/imdb/p2SV.pl?Function=getSurvey $\&$ SDDS $=4450 \&$ lang $=e n \& d b=i m d b$ $\underline{\& d b g}=\mathrm{f} \& \mathrm{adm}=8 \& \mathrm{dis}=2$ (access date: May 11,2018 ).

Office of the Child and Youth Advocate Alberta. 2018. Summary Report: Five Years of Investigations, April 1, 2012 - March 31, 2017. Edmonton: Alberta. http:// www.ocya.alberta.ca/wp-content/uploads/2014/08/OCYARpt_2018_Investigations_FiveYearSummary.pdf (access date: April 30, 2018).

Offord Centre for Child Studies. 2016a. Importance of the EDI. Hamilton. McMaster University. https://edi.offordcentre.com/parents/importance-of-the-edi/_access date: May 15, 2018).

Offord Centre for Child Studies. 2016b. What is the EDI? https://edi.offordcentre. com/about/what-is-the-edi/ (access date: April 13, 2018).

Offord Centre for Child Studies. 2016c. History of the EDI. https://edi.offordcentre. com/about/history-of-the-edi/ (access March 24, 2018).

Offord Centre for Child Studies. 2016d. Requirements/responsibilities of EDI users. https://edi.offordcentre.com/researchers/requirementsresponsibilities-of-ediusers/ (access date: April 17, 2018).

Offord Centre for Child Studies. 2018. FAQ. https://edi.offordcentre.com/researchers/faq/ (access date: December 31, 2018).

Ontario Human Rights Commission. 2018. Interrupted Childhoods: Over-Representation of Indigenous and Black Children in Ontario Child Welfare. Toronto: Ontario Human Rights Commission. http://www.ohrc.on.ca/en/interruptedchildhoods $\# 2$. Why $\% 20$ is $\% 20$ collecting $\% 20$ race-based $\% 20$ data $\% 20$ important? (access date: November 7, 2018).

Peers, Christopher. 2011. The Australian Early Development Index: Reshaping family-child relationships in early childhood education. Contemporary Issues in Childhood 12(2):134-147.

Pentecost, M. and T. Cousins. 2017. Strata of the political: Epigenetic and microbial imaginaries in post-Apartheid Cape Town. Antipode 49(5):1368-1384.

Petersen, Erik L. 2016. The Life Organic: The Theoretical Biology Club and the Roots of Epigenetics. Pittsburgh: University of Pittsburgh Press.

Picherack, Frances and J. Fraser Mustard. 2002. Early Child Development in British Columbia: Enabling Communities. Toronto: The Founders' Network.

Pickersgill, Martyn. 2016. Epistemic modesty, ostentatiousness and the uncertainties of epigenetics: On the knowledge machinery of (social) science. Sociological Review 64(1):186-202.

Population Data BC. 2016. History of the health services data. Vancouver and Victoria: Population Data BC. https://www.popdata.bc.ca/dataaccess/history (access date: April 11, 2018). 
Population Data BC. 2017. BC Perinatal Data Registry. Vancouver and Victoria: Population Data BC. https://www.popdata.bc.ca/data/internal/health/PSBC (access date: April 11, 2018).

Representative for Children and Youth. 2013. When Talk Trumped Service: A Decade of Lost Opportunity for Aboriginal Children and Youth in BC. Victoria, BC: Representative for Children and Youth. https://rcybc.ca/sites/default/files/ documents/pdf/reports publications/when talk trumped service.pdf (access date: August 21, 2018).

Richardson, Sarah S. 2017. Plasticity and programming: Feminism and the epigenetic imaginary. Signs: Journal of Women in Culture and Society 43(1):29-52.

Robison, Shea K. 2018. Epigenetics and Public Policy. Santa Barbara: ABC-CLIO, LLC.

Rose, Nikolas. 1996a. Identity, genealogy, history. In Questions of Cultural Identity, edited by Stuart Hall and Paul Du Gay, 128-149. London: Sage.

Rose, Nikolas. 1996b. Power and subjectivity: Critical history and psychology. In Historical Dimensions of Psychological Discourses, edited by Carl F. Graumann and Kenneth J. Gergen, 103-124. Cambridge: Cambridge University Press.

Rose, Nikolas. 2007. The Politics of Life Itself: Biomedicine, Power, and Subjectivity. Princeton: Princeton University Press.

Rothstein, Mark A., Yu Cai, and Gary E. Marchant. 2009. The ghost in our genes: Legal and ethical implications of epigenetics. Health Matrix Cleveland 19(1):1-62.

Rothstein, Mark A., Heather L. Harrell and Gary E. Marchant. 2017. Transgenerational epigenetics and environmental justice. Environmental Epigenetics 3(3):1-12.

Rowcliffe, Pippa. 2018. What's coming in 2018? http://earlylearning.ubc.ca/ blog/2018/jan/18/whats-coming-2018/ (access date: May 4, 2018).

Saldaña-Tejeda, Abril and Peter Wade. 2018. Obesity, race and the indigenous origins of health risks among Mexican mestizos. Ethnic and Racial Studies 41(15):2731-2749.

Saldaña-Tejeda, Abril. 2018. Mitochondrial mothers of a fat nation: Race, gender and epigenetics in obesity research on Mexican mestizos. BioSocieties 13(2):434452.

Salmon, Amy. 2004. "It takes a community": Constructing Aboriginal mothers and children with FAS/FAE as objects of moral panic in/through a FAS/FAE prevention policy. Journal of Motherhood Initiatives for Research and Community Involvement 6(1):112-123).

Santos, Rob, Marni Brownwell, Okechukwu Ekuma, Teresa Mayer, and Ruth-Ann Soodeen. 2012. The Early Development Instrument (EDI) in Manitoba: Linking socioeconomic adversity and biological vulnerability at birth to children's outcomes at age 5. Winnipeg, MB: Manitoba Centre for Health Policy, May. 
http://mchp-appserv.cpe.umanitoba.ca/reference/MCHP EDI Report WEB. pdf (access date: November 11, 2017).

Saulnier, Katie M. and Charles Dupras. 2017. Race in the postgenomic era: Social epigenetics calling for interdisciplinary ethical safeguards. The American Journal of Bioethics 17(9):58-60.

Schonert-Reichl, Kimberly. 2017. Early Development Instrument parent/guardian information letter. Copy with author.

School Act, 1996, Revised Statutes of British Columbia. www.bced.gov.bc.ca/legislation/schoollaw/revisedstatutescontents.pdf (access date: May 30, 2013).

Simpson, Audra. 2014. Mohawk Interruptus: Political Life across the Borders of Settler States. Durham, NC: Duke University Press.

Simpson, Audra. 2016. Consent's revenge. Cultural Anthropology 31(3):326-333.

Simpson, Leanne Betasamosake. 2014. Land as pedagogy: Nishnaabeg intelligence and rebellious transformation. Decolonization : Indigeneity, Education \& Society $3(3): 1-25$.

Sinha, Vandna, Ashleigh Delaye and Britanny Orav-Lakaski. 2018. Reimagining overrepresentation research: Critical reflections on researching the overrepresentation of First Nations children in the child welfare system. Journal of Law and Social Policy 28 (1):10-38.

Stallins, J., Derek M. Law, Sophia A. Strosberg, and Jarious J. Rossi. 2018. Geography and postgenomics: How space and place are the new DNA. GeoJournal 83:153-168.

Trocmé, Nico. 1994. Ontario incidence study of reported child abuse and neglect. Toronto: University of Toronto, Faculty of Social Work. https://www.attorneygeneral.jus.gov.on.ca/inquiries/cornwall/en/hearings/exhibits/Nico_Trocme/ pdf/OIS 1994.pdf (access date: May 20, 2018).

Trocmé, Nico, Bruce MacLaurin, Barbara Fallon, Joanne Daciuk, Diane Billingsley, Marc Tourigny, Micheline Mayer, John Wright, Ken Barter, Gale Burford, Joe Hornick, Richard Sullivan, Brad McKenzie. 2001. Canadian Incidence of Reported Child Abuse and Neglect. Ottawa: Ministry of Public Works and Government Services. https://www.canada.ca/content/dam/phac-aspc/migration/phac-aspc/publicat/cisfr-ecirf/pdf/cis e.pdf (access date: 20 April 2018).

Trocmé, Nico and David Wolfe. 2001. Child Maltreatment in Canada: Selected Results from the Canadian Incidence of Reported Child Abuse and Neglect. Ottawa: Ministry of Public Works and Government Services Canada. https:// www.canada.ca/content/dam/phac-aspc/migration/phac-aspc/publicat/cissrecirc/pdf/cmic e.pdf (August 19, 2018).

Trocmé, Nico, Barbara Fallon, and Bruce MacLaurin. 2011. Canadian Incidence Study of Reported Child Abuse and Neglect: Changing patterns of reported maltreatment, 1998 and 2003. In Child Welfare: Connecting Research, Policy, and Practice, 2nd edition, edited by Kathleen Kufeldt and Brad McKenzie, 23-35. Waterloo: Wilfrid Laurier Press. 
Turpel, Mary Ellen. 2011. Fragile Lives, Fragmented Systems: Strengthening Supports of Vulnerable Infants. Representative for Children and Youth, BC. Victoria. http://cwrp.ca/sites/default/files/publications/en/BC-Fragile_Lives.pdf (access date: May 10, 2018).

Truth and Reconciliation Commission of Canada. 2015. Honouring the Truth, Reconciling for the Future: Summary Final Report of the Truth and Reconciliation Commission of Canada, Volume One: Summary. Ottawa, ON: Truth and Reconciliation Commission of Canada. http://www.trc.ca/websites/trcinstitution/ File/2015/Findings/Exec Summary 20150531 web o.pdf (access date: January 10, 2018).

Union of British Columbia Indian Chiefs. 2002. Calling Forth our Future: Options for the Exercise of Indigenous Peoples' Authority in Child Welfare. https:// web.archive.org/web/20071008130255/http://www.ubcic.bc.ca/files/PDF/ UBCIC_OurFuture.pdf (access date: November 6, 2008).

Waggoner, Miranda R. and Tobias Uller. 2015. Epigenetic determinism in science and society. New Genetics and Society 34(2):177-195.

Wastell, David and Susan White. 2017. Blinded by Science: The Social Implications of Epigenetics and Neuroscience. Bristol: Policy Press. Digital.

Weir, Lorna. 2006. Pregnancy, Risk and Biopolitics: On the Threshold of the Living Subject. London and New York: Routledge.

West Langley Elementary. 2013. StrongStart - West Langley Elementary. https:// westlangleylionspride.files.wordpress.com/2013/06/september-2013.pdf (access date: May 6, 2018).

White, Linda A. 2017. Constructing Policy Change: Early Childhood Education and Care in Liberal Welfare States. Toronto: University of Toronto Press. Digital.

Wolfe, Patrick. 2008. Structure and event: Settler colonialism, time, and the question of genocide. In Empire, Colony, Genocide: Conquest, Occupation, and Subaltern Resistance in World History, edited by A. Dirk Moses, 102-132. New York and Oxford: Berghahn Books.

Words of Justice. nd. Michel Foucault. Roof garden wall - Left center panel. Harvard Law Library, http://library.law.harvard.edu/justicequotes/explore-the-room/ south-2/ (access date: October 29, 2018).

Karen Bridget Murray is Associate Professor of Politics at York University, where she teaches courses on democratic administration, urban governance, and Canadian politics in comparative perspective. Placing Canada in global and transnational perspective, her engaged research evaluates and theorizes changing norms and forms of modernity and the political and governmental ramifications of these transformations, both as they pertain to cities, as well as to the governance of families and children, including with respect to the settler-colonial present.

Email: murrayk@yorku.ca 